\title{
Digital culture, copyright and the orphan works issue: a view from Brazil*
}

\section{Paula Westenberger}

*This is the author's copy of the chapter by Paula Westenberger, "Digital culture, copyright and the orphan works issue: a view from Brazil" in Pedro Fortes, Larissa Boratti, Andrés Palacios Lleras and Tom Gerald Daly (eds) Law and Policy in Latin America: Transforming Courts, Institutions, and Rights (Palgrave Macmillan 2017) 293-309. Please refer to the Palgrave Macmillan publication for the edited version.

\section{Abstract}

This chapter addresses the issues of orphan works and digitisation by cultural institutions against the backdrop of current discussions in the international copyright policy agenda and existing proposals for national legal developments. The topic is analysed from constitutional and human rights perspectives in contrast with specific copyright provisions. Focus is given to Brazil, where the topic was included in the public consultation for Copyright Law reforms. It is suggested that the proposed amendments do not sufficiently promote the digital dissemination of works and that a more comprehensive solution to the orphan works issue should be developed in the context of mass digitisation by cultural institutions for specific cultural purposes. The relevance of creating an evidence base for orphan works and mass digitisation issues in Latin America is highlighted.

\section{Introduction}

Currently one of the main topics of discussion on the international copyright policy agenda ${ }^{1}$, the digitisation of libraries and archives and the issue of orphan works are deemed illustrative of the extent to which copyright law may impose obstacles to the promotion and preservation of culture. Works are deemed 'orphans' when the copyright owner cannot be identified or located ${ }^{2}$, resulting in the impossibility of obtaining authorisation for preserving and disseminating culturally valuable material ${ }^{3}$.

The fact that authorisation is required for digitising and making works accessible online creates the obligation for cultural institutions ${ }^{4}$ to identify and locate every copyright owner in order to ask permission for such uses. The process of clearance of rights is overly expensive and time-consuming, and unauthorised uses 
entail potential liability for copyright infringement. This situation often prevents cultural institutions from adopting digital technology to preserve and disseminate works, resulting in the 'locking up' of culturally relevant material'.

While access to culture should be promoted as a human right and as an essential tool for social development, cultural institutions still need to respect authors' rights, which also have a human rights basis of protection and are subject to complex international and national regulation.

Although the issues of mass digitisation and orphan works have been assessed and addressed in some jurisdictions, Latin American countries still lack a comprehensive solution. The Regional Centre for Book Development in Latin America and the Caribbean (CERLALC), established by UNESCO, notes that existing solutions for digitisation focus on preservation rather than promoting wider accessibility to works ${ }^{6}$. CERLALC also pointed out that orphan works had not yet been directly addressed in Latin American and Caribbean legislations, which resulted in the need for the promotion of studies on their quantitative, economic and social impact in the region ${ }^{7}$.

Current discussions at the World Intellectual Property Organization (WIPO) focus in finding an international solution to the copyright-related issues faced by libraries and archives, including those related to digitisation and orphan works, and have received the input of several Latin American countries ${ }^{8}$. However, finding a balanced solution to the orphan works problem is a very complex task in view of the diverse demands of the various stakeholders involved ${ }^{9}$. This chapter will suggest that partial legislative solutions at national levels, justified by the public interest in preservation of and access to culture, can already be formulated ${ }^{10}$ to address both the digitisation and the orphan works issues in the context of cultural institutions in Latin 
America.

Brazil will be examined in view of existing legislative proposals, as contemplated in the Copyright Law reform project, submitted to public consultation in 2010. The timing is therefore appropriate for discussions that could help inform the legislator in drafting the relevant provisions.

There is also extra relevance in analysing the Brazilian perspective given that Brazil is being considered a potentially influential world leader in terms of Internet rights as a result of the recent implementation of the 'Internet Bill of Rights" ${ }^{\text {,1 }}$, which includes provisions that, inter alia, guarantee freedom of expression online ${ }^{12}$. In this regard, prospective developments in copyright law concerning digitisation and orphan works could become a reference to Latin American countries. Furthermore, the Brazilian National Library, which owns the richest bibliographical collection in Latin America ${ }^{13}$, is currently undertaking an extensive digitisation project ${ }^{14}$, and could therefore serve as an important case study on this topic.

This chapter suggests that the main challenges faced by cultural institutions regarding orphan works, including operational impacts and potential liability connected to unauthorised uses of such works, actually result from the lack of legal provisions authorizing broader digitisation activities. It is argued, in this regard, that the proposed legislation in Brazil does not sufficiently address the issues associated with digitisation and orphan works in cultural institutions vis a vis the human right to take part in cultural life and the constitutional rights to education and culture.

\section{Digitisation, orphan works and cultural institutions: from human rights to international copyright law}

Access to the Internet is a key means for individuals to exercise the right to 
freedom of expression and, hence, a facilitator in the realisation of other human rights, such as the right to education and to taking part in cultural life ${ }^{15}$. Indeed, the Internet serves as a major catalyst for the distribution of culture that is low in cost and high in reach, which, combined with developments in digital technologies, permit the proper preservation of and access to works and expand the possibilities of creative expressions ${ }^{16}$.

In this scenario, the digitisation projects being undertaken by cultural institutions around the world in order to promote the access to and preservation of their collections ${ }^{17}$ have an important human rights justification, and governments have a mission to provide a legal framework that makes these projects feasible.

According to the Committee on Economic, Social and Cultural Rights (CESCR) of the United Nations, the right to take part in cultural life ${ }^{18}$ requires that the States take actions 'ensuring preconditions for participation, facilitation and promotion of cultural life, and access to and preservation of cultural goods', 'culture' being interpreted as encompassing, inter alia, oral and written literature, music and song, non-verbal communication, arts and other forms of human expression ${ }^{19}$. The elements necessary for the full realisation of such right include, amongst others, (i) the availability of cultural goods and services for everyone, including libraries, museums, theatres, cinemas and the arts in all forms and (ii) the accessibility to cultural goods and services, consisting of 'effective and concrete opportunities for individuals and communities to enjoy culture fully, within physical and financial reach for all in both urban and rural areas, without discrimination, ${ }^{20}$.

On the other hand, copyright also has a human rights basis of protection ${ }^{21}$. It is worth pointing out, however, CESCR's interpretation that 'the scope of protection of the moral and material interests of the author provided for by article 15, paragraph 
1 (c), does not necessarily coincide with what is referred to as intellectual property rights under national legislation or international agreements'; in fact, the protection of moral and material interests of authors is 'intrinsically linked' to other article 15 rights in the Covenant, including the right to take part in cultural life ${ }^{22}$.

However, some aspects of copyright law constitute obstacles to the promotion and dissemination of digital culture in so far as digitising for preservation and dissemination of works on the Internet requires the authorisation of the copyright owner according to international copyright rules. Such rules concern the exclusive right held by copyright owners of authorising the reproduction ${ }^{23}$ and the communication to the public ${ }^{24}$ of their works, including making available online.

It is possible to include some specific uses in copyright legislation that do not require the authorisation of the copyright owner; these are known as limitations and exceptions to copyright. However, they must comply with the 'three-step test', foreseen in the main international copyright treaties ${ }^{25}$, which establishes that exceptions to copyright have to be conceived (i) in certain special cases, (ii) that do not conflict with a normal exploitation of the work and (iii) do not unreasonably prejudice the legitimate interests of the copyright owner ${ }^{26}$. This means that a provision that allows the digitisation and dissemination of copyright works by cultural institutions should comply with the three-step test ${ }^{27}$.

In view of the above, unless the work is in the public domain or the use is legally permitted by a limitation or exception to copyright, cultural institutions must obtain authorisation of the owner of the copyright prior to the digitisation and dissemination of their works. Such clearance of rights might be unfeasible, due to time and cost issues, or unsuccessful, in the case of orphan works, resulting in the 'locking up' of culturally relevant material. 
In the United Kingdom, orphan works were found to generate a significant operational impact on the functioning of a cultural institution ${ }^{28}$, which showed the urgency in addressing the issue. The United States Copyright Office has developed an extensive study dedicated to orphan works and mass digitisation ${ }^{29}$, concluding that solutions for such issues were 'desperately needed' and proposing legislative responses $^{30}$.

There are no such impact studies on orphan works in relation to Latin American countries, which is a point to be considered in copyright policy, as pointed out by CERLALC.

\section{Existing solutions for the orphan works issue internationally}

There are a variety of solutions being devised worldwide to address digitisation and orphan works issues ${ }^{31}$. One question to be answered is whether any of these solutions allow the creation of a digital cultural environment that addresses specific demands for access to culture in Latin America, in a manner that is balanced with the interests of right holders ${ }^{32}$. It is suggested here, however, that, to assist formulating their own solutions, Latin American countries could employ the methodologies of the studies that supported policy discussions in other countries.

Even though the Canadian compulsory licensing system provides legal certainty to the user of orphan works, the system has been criticised for its apparent inefficiency, as suggested by the small number of applications filed ${ }^{33}$. The Scandinavian extended collective licensing approach is a possible solution for the issue of mass rights clearance, including for digitisation projects; however, it depends on sufficient representativeness of collective management organisations in those countries, which may not be the same in other jurisdictions ${ }^{34}$, like Brazil, where 
collective management is a contentious matter ${ }^{35}$, which may indicate that such solution may not be widely supported by Brazilian authors ${ }^{36}$. In the United States, although the fair use provision was applied to the Google Books digitisation project ${ }^{37}$, the country still has policy recommendations for implementing legislative solutions specifically for orphan works and mass digitisation. In Europe, Directive $2012 / 28 / \mathrm{EU}^{38}$ was issued to regulate certain uses of orphan works by cultural institutions and the UK has passed legislation in 2014 for an orphan works licensing scheme to be carried out by the Intellectual Property Office and for an extended collective licensing scheme, as well as for an exception for certain uses of orphan works by cultural institutions, implementing the EU Directive ${ }^{39}$.

In the absence of legal solutions in some jurisdictions, cultural institutions are either digitising orphan works without authorisation and relying on a risk management policy or are refraining from using modern preservation technologies for orphan works ${ }^{40}$. The general policy underpinning the 'BN Digital' digitisation project of the National Library in Brazil, for example, is only making available works in the public domain, unless authorisation of the copyright owners is obtained $^{41}$.

\section{The Brazilian copyright system and constitutional rights}

The issue of orphan works is not currently addressed in the Brazilian Copyright $\mathrm{Law}^{42}$, which also does not contain limitations to copyright aimed at cultural institutions. The proposals of copyright reform addressed these issues, but still not providing a comprehensive solution in view of the human and fundamental rights to access to culture.

Cultural institutions hold in their collections various forms of copyright 
protected material ${ }^{43}$. Unless the work is in the public domain ${ }^{44}$, digitisation and dissemination online by a cultural institution would require the authorisation of the copyright owners. Authors' exclusive right of use, publication or reproduction of their works are fundamental rights in the Brazilian Constitution ${ }^{45}$ and are protected under the category of economic rights in the Copyright $\mathrm{Law}^{46}$. Authors also own moral rights, which include, inter alia, the rights to be named as author, to keep a work unpublished and to retract a published work when it affects their reputation ${ }^{47}$.

The ownership of rights is another complex element. In order to digitise and make a work available, permission must be obtained from the copyright owner, who can be the author (natural person who creates a work) ${ }^{48}$, a legal entity (e.g. collective works, although individual collaborations need to be independently authorized where they can be individualized) ${ }^{49}$ or a third-party that acquired ownership through contract or inheritance. The lack of formalities over the protection of a work, i.e. no need for registration ${ }^{50}$, entails difficulties for rights clearance. Uses that may interfere with moral rights are enforceable by authors, their heirs, the director of a film, and sometimes even the State, and even though copyright can be assigned, moral rights are inalienable ${ }^{51}$.

The closest provisions in the Brazilian Law dealing with unknown ownership of rights are those on anonymous works and works of unknown authorship. However, these cannot be considered solutions to the orphan works issue due to the lack of clarity of these provisions and to their limited scope compared to the orphan works definition.

Anonymous works are defined in legislation as 'any work that does not name the author, either according to his wish or because he is unknown, ${ }^{52}$. The first issue is that the law fails to clearly define anonymous works and works of unknown 
authorship, even though it provides different legal treatments to these works: anonymous works are owned by the publisher ${ }^{53}$ while works of unknown authorship belong to the public domain ${ }^{54}$. Such drastic differences in ownership with no clear distinction between the definitions of these works result in an unclear rule for their use.

There is disagreement amongst scholars on the application of these provisions. Fragoso understands that anonymous works will belong to the public domain until the author makes him or herself known, although admitting that this interpretation has a potential to create issues for the users of these works ${ }^{55}$. Branco disagrees, arguing that anonymous and unknown authorship are different concepts since the law determines a specific deadline of protection for anonymous works, being incompatible with the rule of the public domain, and defending that in the case of anonymous works, the author did not want to be known, while in the case of works of unknown authorship, the authorship became unknown over the course of time ${ }^{56}$. However, there is no straightforward way of assessing whether authors are not identified according to their wish or because this information was lost in time, which creates a practical obstacle in applying the relevant rules.

To add further complexity to the discussion, a recent decision by the Superior Court of Justice, has indicated, citing the commentator Elisângela Dias Menezes, that 'anonymous and pseudonymous works can be freely represented, performed, published or in any way utilised without the consent of the author, since the author cannot be identified ${ }^{57}$.

Furthermore, the provisions on anonymous works and unknown authorship do not sufficiently cover orphan works as they only refer to the unnamed or unknown author, not mentioning where the owner of copyright is unknown, and they would 
not apply to the situations where the author or owner is indeed known, but not located, which are also within the definition of orphan works ${ }^{58}$.

As regards the lack of limitations to copyright in Brazilian law concerning the use of works by cultural institutions, it is important to clarify that the Brazilian limitations clauses ${ }^{59}$ have been traditionally interpreted to be exhaustive and narrowly construed ${ }^{60}$. However, another recent decision by the Superior Court of Justice has clarified that the limitations clauses in the Copyright Law should be deemed illustrative, considering the fundamental rights at stake and applying the three-step test ${ }^{61}$.

In the case of digitisation of works by cultural institutions, the constitutional rights that are relevant to the discussion include the fundamental right to education ${ }^{62}$, which shall be provided based on the 'freedom to learn, teach, research and express thought, art and knowledge ${ }^{63}$; the fundamental right of access to information ${ }^{64}$; and cultural rights and access to the sources of national culture, which should be guaranteed by the State, who should support and encourage the dissemination of cultural expressions, as well as promote and protect (including with measures of preservation) Brazilian cultural heritage, which comprise, inter alia, forms of expression and artistic creations ${ }^{65}$.

It can be said that the Constitution itself contains provisions that could be interpreted by the Courts in order to allow certain cases of digitisation by public institutions without the need of authorisation, applying the understanding of the recent decision in Special Appeal REsp 964.404. However, considering Brazil is a civil law jurisdiction, relying solely on the case law approach may not provide the legal certainty needed for cultural institutions to carry out their digitisation projects.

In view of the above, the Brazilian Copyright Law may not be sufficiently 
balanced with the human and constitutional rights at stake by not allowing the digitisation of works for preservation and access to culture.

\section{Projects of reform of the Brazilian Copyright Law}

Discussions on the need to update the Brazilian Copyright Law culminated with the Ministry of Culture's submission of a project of reform to public consultation in $2010^{66}$. After the public consultation, some amendments to the original project were proposed ${ }^{67}$. Under a three-step test traditional perspective, it can be said the amended proposals comply with the interests of rights owners. But questions remain as to whether they are compatible with social and cultural interests, and, in this regard, the main problems that should be addressed are preservation and accessibility, including online. On this point, it is important to highlight that the mission of the Brazilian National Library's digitisation project is to preserve the cultural memory and promote wide access to information ${ }^{68}$.

\section{(i) Preservation}

The project submitted to public consultation included a provision specifically allowing cultural institutions to reproduce works for the purposes of conservation, preservation and archiving, without commercial purpose ${ }^{69}$. Since no authorisation is required, orphan works would not be an issue for the purposes of preservation.

This solution can be considered three-step test compliant, arguably even under its more conservative approach. It is also, to a certain extent, human and constitutional rights effective as it allows culture to be preserved. However, a question to be asked is whether the concept of preservation of culture should be limited to the reproduction of a work for digital storage or tangible substitution, or if 
it should be more widely interpreted to include measures for digitally disseminating such works to the public ${ }^{70}$.

\section{(ii) Accessibility}

The public consultation project also proposed a provision to allow cultural institutions to communicate and make available to the public the works in their collections, for the purposes of research, investigation or study, within their facilities or through their closed computer networks ${ }^{71}$. As a limitation to copyright, this solution would cover works irrespective of their orphan status.

After the public consultation, the proposed amendment imposed further restrictions to such provision, including that it would only apply to works that were rare or unavailable to purchase and in order to avoid deterioration.

It can be argued that this limitation to copyright should not be restricted to the communication and making available of works within the facilities of cultural institutions; it should also allow, in specific circumstances, the making available on online platforms managed by the cultural institution. Since not everyone is able to personally visit cultural institutions, narrowing down the access in this manner would be a 'retrograde step in an era of digital culture' ${ }^{72}$ and not consistent with the human right of participating in cultural life. This is particularly so in a country of the territorial dimensions and social inequalities of Brazil. Restricting the provision to uses that aim to avoid deterioration and, cumulatively, to works that are rare or unavailable, as reads the proposed amendment, might also be a too narrow formulation.

Relying on the balanced interpretation of the three-step test ${ }^{73}$, it is important to allow the reproduction and communication of certain works by cultural institutions 
for certain non-commercial cultural uses, both 'cultural institutions' and 'cultural uses' having to be carefully defined ${ }^{74}$. It may be necessary to make a distinction between different categories of works in such limitation, possibly including 'orphan works' in its formulation. Including a low resolution picture of a painting on a museum's website for visitor information purposes, for example, has arguably a lower impact to the copyright owner than including the full content of an incopyright, non-orphan, book on a library's website. A too widely drafted limitation could violate the three-step test, and a possible solution could be to include a few examples of allowed uses alongside a three-step test wording, akin to article 46, VIII of the Copyright Law.

It is therefore crucial that the drafting of this limitation is supported by robust evidence and studies on, inter alia, the functioning of different types of cultural institutions and their engagement with copyright law, on the current processes of acquisition, lending and online dissemination of works and on the contractual architecture involving cultural institutions and rights owners.

\section{(iii) Specific provisions on orphan works}

A system of non-voluntary non-exclusive licences, including, inter alia, orphan works, was also proposed ${ }^{75}$. The proposed amendment after the public consultation created a provision exclusively for orphan works, which would be licensed by the Ministry of Culture, improving the solution as it separated it from other materials (e.g. out of print works), established the allocation of resources, included the need for reasonable and good faith search for authors (akin to the diligent search requirement in other jurisdictions) and removed some of the restrictions that were imposed in the former proposal ${ }^{76}$. A suggestion that could be 
made is that article 52-C, $\S 1$ should mention 'owners', while it currently foresees the reasonable search only for 'authors'.

The amended proposal created a balanced licensing solution for orphan works and could be implemented in conjunction with the preservation and accessibility limitations proposed above, as it could possibly allow non-cultural or commercial uses of orphan works. Such uses are, however, arguably less urgent than the cultural uses proposed as limitations ${ }^{77}$, and as such should not delay the implementation of the latter.

(iv) Problems not addressed in the projects of reform

No attempt was made to clarify the difference between anonymous works and works of unknown authorship, which are concepts that could create confusion with the definition of orphan works. Suggestions in this sense are to re-define anonymous works in order to remove 'works of unknown authorship' from its definition; clarify that where the publisher of anonymous works cannot be identified or located these works could also be considered orphan works; and clarify and re-name the works of "unknown authorship" that belong to the public domain under article 45, II.

Lastly, the digitisation solutions for cultural institutions should be dissociated from the wider copyright law reform in order to expedite the passing of new legislation, as occurred with the collective management reforms.

\section{Conclusion}

The orphan works issue is real, and it is possible to find a partial solution through legislative amendments that comply with international copyright requirements. A solution that responds to current demands relating to digital culture 
in Brazil, however, should not be restricted to orphan works, but must be thought in the general context of digitisation by cultural institutions.

It was argued, in this sense, that by creating a general solution for digitisation by cultural institutions, the most urgent issues related to orphan works (preservation and access) are resolved, which can lead to the conclusion that the magnitude of the orphan works issue is only real in so far as there are no adequate digitisation solutions.

The system being discussed in the reform proposals in Brazil does not appear to fulfil the full potential of the fundamental right of participating in cultural life and the constitutional rights of access to culture, information and education, as solutions for an effective dissemination of cultural materials are still required. However, it is vital that the drafting of such limitation is informed by substantive study and evidence on the current practices of cultural institutions in dealing with copyright works. Empirical methodologies employed in other jurisdictions' studies could also be used in Brazil. Initiatives such as the cooperation between the Ministry of Culture and Europeana in the context of the 'Information Systems and Digital Cultural Collections' action within the project 'Sectorial Dialogues European Union-Brazil', including discussions on copyright, should be highly welcomed ${ }^{78}$. 
1 E.g. WIPO's sessions SCCR/26 of 2013 to SCCR/30 of 2015. $<$ www.wipo.int/meetings/en/topic.jsp?group_id=62> accessed 16 October 2015.

${ }^{2}$ VUOPALA, A. Assessment of the Orphan works issue and Costs for Rights Clearance. European Commission DG Information Society and Media Unit E4 Access to Information, May 2010, pp. 11-12.

${ }^{3}$ In UK public sector organisations, works likely to be orphans have arguably little commercial value, but high academic and cultural significance. KORN, N. In from the Cold: An assessment of the scope of 'Orphan Works' and its impact on the delivery of services to the public. JISC, April 2009, p. 6.

${ }^{4}$ For the purposes of this chapter, 'cultural institutions' are 'libraries, archives, documentation centres, museums, film archives and other museum institutions', following reform proposal of article 46, Brazilian Copyright Law under public consultation in 2010.

${ }^{5}$ KORN, N, op. cit. p. 6.

${ }^{6}$ In 2012, sixteen of CERLALC members had a copyright limitation for libraries, the majority of them only allowing the tangible reproduction of the work required for preservation or substitution of a permanent collection item, whereas only Chilean legislation allowed the electronic reproduction to be consulted in a closed network. CERLALC Circular No. 02, 16 Mar. 2012, p. 12. For a comparison of legislations, see Annex 2. <www.cerlalc.org/Circular_Bibliotecas_Digitales.pdf $>$ accessed 18 October 2015.

${ }^{7}$ Ibid., p. 18.

${ }^{8}$ In 2011, Brazil, Ecuador and Uruguay (referring to the earlier African Group proposal) made proposals for limitations for libraries and archives (SCCR/23/5) $<$ www.wipo.int/meetings/en/details.jsp?meeting_id $=22210>$ accessed 8 November 2015. In 2013, working document SCCR/26/3 with comments and suggestions, including from Argentina, Brazil, Chile, Ecuador, Mexico and Uruguay, was adopted by the committee. <www.wipo.int/edocs/mdocs/copyright/en/sccr_26/sccr_26_3.pdf> accessed 18 October 2015.

${ }^{9}$ E.g. heritage institutions and commercial users versus authors and rights holders concerned with lack of diligent searches and malicious interference in digital files (the 'fake orphans') and with the lack of proper evidence about the extent of the orphan works issue. CORBETT, S. op. cit. p. 182.

${ }^{10}$ Similarly, Corbett concludes that "a partial solution for cultural heritage orphans should not be delayed", in particular in net copyright importing countries like New Zealand, where the cultural heritage aspect is more immediately significant than the economic one. Ibid. p. 196.

${ }^{11}$ Law no 12.965/2014 (the Internet 'Marco Civil').

${ }^{12}$ PATRY, M. Brazil: A new global internet referee? Policy paper on digital freedom of expression in Brazil, Index: June 2014, p. 2. <www.indexoncensorship.org/wpcontent/uploads/2014/06/brazil-internet-freedom_web_en.pdf $>$ accessed 18 October 2015.

${ }^{13}$ TADDEI, R. Políticas públicas para acervos digitais: propostas para o Ministério 
da Cultura e para o setor. São Paulo, 15 June 2010, p. 34. $<\mathrm{http}$ ://culturadigital.br/simposioacervosdigitais/2010/06/30/politicas-publicas-paraacervos-digitais-propostas-para-o-ministerio-da-cultura-e-para-o-setor/ $>$ accessed 9 November 2015.

${ }^{14}$ The digital collection of the Brazilian National Library currently holds more than one million documents: <http://bndigital.bn.br> accessed on 18 October 2015.

${ }^{15} \mathrm{UN}$, 'Report of the Special Rapporteur on the promotion and protection of the right to freedom of opinion and expression, Frank La Rue'. A/HRC/17/27. 16 May 2011, p. 7. <www2.ohchr.org/english/bodies/hrcouncil/docs/17session/A.HRC.17.27_en.pdf> accessed 18 October 2015.

${ }^{16}$ SHAVER, L. and SGANGA, C., The Right to Take Part in Cultural Life: On Copyright and Human Rights, Wisconsin International Law Journal 27 (2010), p. 649-650 and TADDEI, R. op. cit. p. 4.

${ }^{17}$ On Brazilian digitisation projects, see TADDEI, R. op. cit. p. 4.

${ }^{18}$ Article 27(1) of the Universal Declaration of Human Rights 1948 ('UDHR'); article 15.1.a of the United Nation's International Covenant on Economic, Social and Cultural Rights 1966 ('ICESCR').

${ }^{19}$ UN, General Comment 21 (2009), pp. 2-4.

${ }^{20}$ Ibid. pp. 4-5.

${ }^{21}$ Article 27 (2) of the UDHR and article 15.1.c of the ICESCR.

${ }^{22}$ UN, General Comment 17 (2005), pp. 2-3. Further discussion on the human rights dimension of copyright in 'Report of the Special Rapporteur in the field of cultural rights, Farida Shaheed', UN Human Rights Council, 24 December 2014.

${ }^{23}$ Article 9(1) of the Berne Convention for the Protection of Literary and Artistic Works 1886 ('Berne Convention'). Digitisation is a form of reproduction: Agreed Statement concerning Article 1(4) of the WIPO Copyright Treaty 1996 $<$ http://www.wipo.int/treaties/en/ip/wct/statements.html> accessed 19 October 2015.

${ }^{24}$ Article 8 of the WIPO Copyright Treaty.

${ }^{25}$ Article 9(2), Berne Convention; Article 13, WTO Agreement on Trade-Related Aspects of Intellectual Property Rights 1994 ('TRIPS').

${ }^{26}$ The WTO Dispute Settlement Body decided on the interpretation of the three-step test, stating, inter alia, that limitations and exceptions should be clearly defined and narrow in scope and reach (Panel Rep. of 15 June 2000, WT/DS160/R, p. 34). Scholars promoted a declaration about the need for a more balanced application, which rather than a step-by-step approach, required a comprehensive overall assessment, considering a balancing of interests of rights holders and general public, particularly in cases involving fundamental rights. GEIGER, HILTY, GRIFFITHS, SUTHERSANEN [2010] 'Declaration: A Balanced Interpretation Of The "ThreeStep Test" In Copyright Law'. jipitec, Vol. 1, pp. 119-120 $<$ http://www.jipitec.eu/issues/jipitec-1-2-2010/2621/Declaration-BalancedInterpretation-Of-The-Three-Step-Test.pdf $>$ accessed 9 November 2015.

${ }^{27}$ Corbett discusses the need for compliance with the three-step test by orphan works legislation. CORBETT, S. op. cit. p. 193. 
${ }^{28}$ Tracing the rights holders for the 13 million works in their on-line survey would take around 6 million days; 25 million orphans estimated in public sector organizations; complex and costly due diligences; orphan works issue growing and preventing cultural institutions from serving the public interest as materials of high academic and cultural value were not made accessible; black hole of $20^{\text {th }}$ century content. KORN, N., op. cit., p. 5-7.

${ }^{29}$ The documents related to the study by the US Copyright Office, from 2005 to the final 2015 report are available at: <www.copyright.gov/orphan/> accessed 18 October 2015.

${ }^{30}$ US Copyright Office, 'Orphan works and mass digitization: a report of the register of copyrights', June 2015, p. $105<$ http://copyright.gov/orphan/reports/orphanworks2015.pdf $>$ accessed 18 October 2015.

${ }^{31}$ See FAVALE, M., HOMBERG, F. et al ' Copyright, and the Regulation of Orphan Works: A comparative review of seven jurisdictions and a rights clearance simulation', 2013. < https://www.gov.uk/government/publications/copyright-and-theregulation-of-orphan-works $>$ accessed 9 November 2015.

${ }^{32}$ For a study on libraries exceptions of the world, including Latin American countries, see CREWS, K.D. 'Study On Copyright Limitations And Exceptions For Libraries And Archives: Updated And Revised' SCCR/30/3, June 10, 2015. As regards exceptions for museums, Chile is the only country in Latin America containing a provision expressly for museums, as per CANAT, J.F. and GUIBAULT, L 'Study on Copyright Limitations and Exceptions for Museums', SCCR/30/2, April 30, 2015, p. 19.

${ }^{33}$ VAN GOMPEL, S. Unlocking the Potential of Pre-Existing Content - How to Address the Issue of Orphan Works in Europe? IIC 669 (2007) p. 694.

${ }^{34}$ RINGNALDA, A. 'Orphan Works, Mass Rights Clearance, and Online Libraries: The Flaws of the Draft Orphan Works Directive and Extended Collective Licensing as a Solution.' Medien und Recht International vol. 8 (2011), p. 10.

${ }^{35}$ ECAD faced a Parliamentary Commission of Inquiry discussing the lack of transparency in managing resources. Law 12853/2013 was enacted to regulate the activities of collecting societies and is being challenged by two proceedings before the Brazilian Supreme Court (ADI 5062 and ADI 5065 filed in November 2013).

${ }^{36}$ However, this scenario could change in view of new collective management legislation.

${ }^{37}$ The Authors Guild, Inc v Google, Inc, US District Court SDNY, 14 November 2013; USCA 2d Circuit, 16 October 2015.

${ }^{38}$ For a detailed analysis of the Directive, see SUTHERSANEN, U and FRABBONI, M. M. 'The Orphan Works Directive' in STAMATOUDI, I and TORREMANS, P (ed) EU Copyright Law: A Commentary. Edward Elgar, 2014, pp. 653-695 and ROSATI, E. 'The Orphan Works Directive, or throwing a stone and hiding the hand' (2013) Journal of Intellectual Property Law \& Practice Vol. 8, No. 4, pp. 303-310.

${ }^{39}<$ http://copyrightuser.org/topics/orphan-works/> accessed 9 November 2015.

${ }^{40}$ CORBETT, S. op. cit. p. 180 and 185. 
${ }^{41}<$ http://bndigital.bn.br $>$ accessed 30 October 2015.

${ }^{42}$ Law No 9610/1998 ('Brazilian Copyright Law'). English translation at UNESCO's website:

$<$ http://portal.unesco.org/culture/en/files/30462/11426147383br_copyright_1998_en. pdf/br_copyright_1998_en.pdf $>$ accessed 18 October 2015.

${ }^{43}$ Article 7, Brazilian Copyright Law.

${ }^{44}$ Generally 70 years after the death of the author, article 41 of the Brazilian Copyright Law.

45 Article 5, XXVII, Brazilian Constitution. English translation available at: $<$ http://english.tse.jus.br/arquivos/federal-constitution $>$ accessed 9 November 2015.

${ }^{46}$ Articles 28, 29 and 30, Brazilian Copyright Law.

${ }^{47}$ Article 24, Brazilian Copyright Law.

${ }^{48}$ Article 11, Brazilian Copyright Law.

${ }^{49}$ Articles 11, Sole Paragraph, 17, §2 and 5, VIII, h, Brazilian Copyright Law.

${ }^{50}$ Article 18, Brazilian Copyright Law and article 5(2), Berne Convention.

${ }^{51}$ Articles 24, $\$ 1$ and $\S 2$ and 27, Brazilian Copyright Law.

52 Art. 5, VIII, b, Brazilian Copyright Law.

${ }^{53}$ Art. 40, Brazilian Copyright Law.

${ }^{54}$ Art. 45, II, Brazilian Copyright Law.

${ }^{55}$ FRAGOSO, J.H. 'Direito Autoral - Da Antiguidade à Internet' São Paulo: Quartier Latin, 2009, p. 332.

${ }^{56}$ BRANCO, S. O domínio público no direito autoral brasileiro. Rio de Janeiro : Lumen Juris, 2011, pp. 170-171.

${ }^{57}$ STJ, Special Appeal REsp 1.322.325 published 14 March 2014.

${ }^{58}$ Regarding other Latin American countries, see CERLALC, op. cit., p. 18.

${ }^{59}$ Articles 46 to 48, Brazilian Copyright Law.

${ }^{60}$ E.g. CABRAL, P. 'A Lei de Direitos Autorais: Comentários', $5^{\text {th }}$ ed., São Paulo: Rideel, 2009, p. 111. Souza discusses exhaustive versus non-exhaustive interpretations of the limitations clause, defending the latter. SOUZA, A. R. 'A Função Social dos Direitos Autorais', Campos dos Goyatcazes: Faculdade de Direito de Campos, 2006, pp. 271-274.

${ }^{61}$ STJ, Special Appeal REsp 964.404 published 23 May 2011.

${ }^{62}$ Article 6, Brazilian Constitution.

${ }^{63}$ Article 206, II, Brazilian Constitution.

${ }^{64}$ Article 5, XIV, Brazilian Constitution.

${ }^{65}$ Articles 215, 216 and 216-A, Brazilian Constitution.

${ }^{66}$ Unofficially translated by ARAÚJO, B.S.R. and GRASSMUCK, V.R. of the Research Group 'GPOPAI' of the University of São Paulo <www.vgrass.de/?p=283> accessed 18 October 2015.

${ }^{67}$ Ministério da Cultura, Secretaria de Políticas Culturais, Diretoria de Direitos Intelectuais, 'Relatório de Análise das Contribuições ao Anteprojeto de Modernização da Lei de Direitos Autorais (após a consulta pública realizada de 14/06 a 31/08/2010 e após debate no Grupo Interministerial de Propriedade Intelectual - GIPI)' 
${ }^{68}<$ http://bndigital.bn.br/sobre-a-bndigital/?sub=missao/ $>$ accessed on 30 October 2015.

${ }^{69}$ Proposed article 46, XIII. Proposed amendment to 'without profit intent' after the public consultation.

${ }^{70} \mathrm{CTS} / \mathrm{FGV}$ 's contribution to the public consultation article 46, XVI indicates 'the reproduction for conservation, preservation and archive has undisputable relevance, but only achieves its full potential if it facilitates the access by interested parties' (original in Portuguese) <www2.cultura.gov.br/consultadireitoautoral/wpcontent/uploads/2010/09/CTS-FGV.pdf $>$ accessed 9 November 2015.

${ }^{71}$ Proposed article 46, XVI.

${ }^{72}$ CORBETT, S. op. cit. p. 194.

${ }^{73}$ GEIGER, HILTY, et. al. op. cit. pp. 119-122

${ }^{74}$ Although not intended as a copyright exception, but as a suggestion for orphan works statutory licensing formulations in the UK, some aspects of Stop 43's definition of 'cultural use' could be used as guidance for the proposed Brazilian limitation. Bearing in mind Brazil's geographical and social particularities, the possibility of adapting such definition to the Brazilian reality should be considered. $<$ http://stop43.org.uk/what we stand for/what we stand for.html\#No_commercial use_of_orphan_wor> accessed 9 February 2016.

${ }^{75}$ Proposed article 52-B, III.

${ }^{76}$ Proposed article 52-C.

${ }^{77}$ See footnote 10 .

${ }^{78}$ Geyzon Dantas, 'Mais um passo para digitalização de conteúdos culturais' 16 October $2015<$ <ww.cultura.gov.br/banner-3//asset_publisher/axCZZwQo8xW6/content/mais-um-passo-para-digitalizacao-deconteudos-

culturais/10883?redirect=http $\% 3 \mathrm{~A} \% 2 \mathrm{~F} \% 2 \mathrm{Fwww}$.cultura.gov.br\%2Fbanner3\%3Fp_p_id\%3D101_INSTANCE_axCZZwQo8xW6\%26p_p_lifecycle\%3D0\%26p_ p_state $\% 3$ Dnormal $\% 26 p \_p \_m o d e \% 3 D v i e w \% 26 p \_p \_c o l \_i d \% 3 D c o l u m n-$ 3\%26p_p_col_count $\% 3 \mathrm{D} 2>$ accessed 9 November 2015. 